\title{
Metacognitive strategies for the development of teaching vocabulary in English
}

\author{
Estrategias Metacognitivas para el desarrollo de la enseñanza de vocabulario en Inglés
}

Estratégias metodológicas para o desenvolvimento do aprendizado do vocabulário em inglês

\section{ARTÍCULO DE INVESTIGACIÓN}

Jeaneth Alexandra Barrionuevo Villacrés

jeaneth.barrionuevo@espoch.edu.ec

https://orcid.org/0000-0003-0884-8324

Sandra Leticia Guijarro Paguay

sandra.guijarro@espoch.edu.ec

https://orcid.org/0000-0002-0413-4925

\section{Lilian Silvana Cajamarca Farez \\ lcajamarcaf@ucacue.edu.ec \\ https://orcid.org/0000-0001-5390-02397}

Christian Octavio Chicaiza Calle

cchicaiza886@gmail.com

https://orcid.org/0000-0003-3642-799X

\section{Escuela Superior Politécnica de Chimborazo, Ecuador Universidad Católica de Cuenca, Ecuador}

Recibido 11 de mayo 2021 | Arbitrado y aceptado 9 de junio 2021 | Publicado en 01 julio 2021

\section{ABSTRACT}

Metacognitive strategies are tools that enhance the construction of meaningful knowledge by inducing reflection on it, proving to be ideal to support learning processes within the framework of the demands of the current knowledge society, where greater training in skills that allow "learning to learn" is required. In this sense, do the teachers of the Language Center of the Catholic University of Cuenca [UCACUE] use metacognitive strategies? What are they and how often do they use them? This study aims to determine to what extent these strategies are used for teaching English vocabulary by the teachers of the center in question. The information was collected through a semi-structured survey created ad hoc, and it was possible to verify the total absence of the use of these strategies within the didactic repertoire of the teachers.

Key words:: Vocabulary; Strategies; Metacognitive; English; Teaching
RESUMEN

Las estrategias metacognitivas son herramientas que potencian la construcción de un conocimiento significativo al inducir a la reflexión sobre el mismo, resultando ser idóneas para apoyar los procesos de aprendizaje en el marco de las exigencias de la actual sociedad de conocimiento, donde se requiere una mayor formación en competencias que permitan "aprender a aprender”. En este sentido, ¿Los docentes del Centro de Idiomas de la Universidad Católica de Cuenca [UCACUE] emplean estrategias metacognitivas? ¿Cuáles son y en qué frecuencia las utilizan? Este estudio tiene como objetivo el determinar en qué medida estas estrategias son empleadas para la enseñanza del vocabulario del idioma inglés por parte del profesorado del centro en cuestión. La información se recabó mediante una encuesta semiestructurada creada ad hoc, lográndose constatar la total ausencia del empleo de estas estrategias dentro del repertorio didáctico de los docentes.

Palabras clave: Vocabulario; Estrategias; Metacognitivas; inglés; Enseñanza

\section{RESUMO}

Estratégias metacognitivas são ferramentas que potencializam a construção de conhecimentos significativos, induzindo a reflexão sobre ele, provando ser ideal para apoiar processos de aprendizagem no âmbito das demandas da sociedade do conhecimento atual, onde é necessária maior formação em habilidades que permitam "aprender a aprender". Nesse sentido, os professores do Centro de Línguas da Universidade Católica de Cuenca [UCACUE] usam estratégias metacognitivas? O que são eles e com que frequência os usam? Este estudo tem como objetivo determinar até que ponto essas estratégias são utilizadas para o ensino do vocabulário da língua inglesa pelos professores do centro em questão. As informações foram coletadas por meio de uma pesquisa semiestruturada criada ad hoc, e foi possível verificar a total ausência do uso dessas estratégias dentro do repertório didático dos professores.

Palavras-chave: Vocabulário; Estratégias; Metacognitivo; Inglês; Ensino 


\section{INTRODUCTION}

To talk and communicate is important due to everyone using the same communication code, that is, the language. Language learning begins with vocabulary and understanding. A broad and sufficient vocabulary allows a good communication.

The vocabulary is not only to list words, but also to combine the lexical elements to communicate ideas with precision. Wilkings (1972), a British linguist states that "Although little grammar can be transmitted, without vocabulary nothing can be transmitted. Someone could read a text almost without using the grammar, but without vocabulary cannot get anywhere" (UK Essays, 2018, p.1). Within this context, the apprentices of a foreign language who do not know the importance of acquiring vocabulary tend to generate a communication problem.

Many researchers agree that for a new language assimilation, the vocabulary should be used in different contexts related to the reality and environment of the learner. Learning vocabulary is a process of accumulating and remembering different words, however, memorizing single words is not effective since meaningful learning understands and relates words to everyday elements and events. The vocabulary allows one to learn and develop other skills in learning a new language such as reading, listening, writing, and speaking (UK Essays, 2018).

Jamaris (2016) points out "researches on the teaching and learning of vocabulary shows that there is no better strategy and that the success of vocabulary learning activities depends on many elements including levels of competence, interests and student's objectives. Exposing language students to as many strategies as possible is ideal. A strategy that is good for one student may not be good for another. Some learners can learn from the context others must be taught explicitly" (p.35-39).

According to García-López (2000) “[...] when referring to vocabulary learning strategies, it will be talking about intentional actions carried out with the purpose of achieving a goal in this case, the learning of vocabulary" (p. 61).

O’Malley, (1990) declares the use of twenty-four strategies employed by English learners in the United States. Larsen-Freeman, (1991) offer a classification taken from O'Malley, grouping the strategies into three groups: Cognitive, Metacognitive and Socio Affective (p. 202-203).

Cognitive strategies Oxford, (1990) points out that cognitive strategies "[...] being very diverse, all share the same functions: the manipulation of the target language, or its transformation, by the student" (pp. 166-172).

Cervantes, (1997) mentioned:

Cognitive strategies constitute a group of learning strategies. They are activities and mental processes that the learners perform consciously or unconsciously; with them theyimprove the understanding of language, its assimilation, its storage in memory, its recovery and its subsequent use. In the learning of a new language the learner has to come to understand, on the one hand, the content of the messages he receives and the texts he reads and, on the other, new rules and new linguistic patterns. In both cases the mind of the learner performs an activity and experiences very similar processes of processing and storing the information obtained. In addition, in the first case, the application of cognitive strategies is combined effectively with communicative strategies.

\section{The cognitive strategies are described briefly as follows}

Repetition.- Is practiced and rehearsed over time and gradually becomes easier. Resourcing considered as any tool that helps teachers teach and students learn, similar to Imagery.- that use the didactic 
materials such as photography, computer images, movies, television shows, computer applications and presentations as support to teaching English

Direct Physical Response.- Based on the idea that if you must do something physical in response to language, then learning is more meaningful, and you learn faster. Translation, a piece of writing or speech that has been translated from a different language.

Grouping.- The process of combining words in groups, the same as Recombination, combining words again in different situations. Also, Key Word a concept of great significance used in an information retrieval system to indicate the content of a document is alike

Contextualization.- Putting language items into a meaningful and real context rather than being treated as isolated items of language.

Note-taking.- Consists in listening to the teacher and writing down a chart of ideas, Deduction, the process of reaching a conclusion about something because of other things that you know to be true; Auditory representation, speech sounds are processed as articulatory gestures facilitate the learning of new knowledge.

Elaboration.- Involves explaining and describing ideas with many details; Transfer, the capacity to apply acquired knowledge and skills to new situations; Inferencing, the practice of inferring the meaning of an unfamiliar word or expression from the meaning of familiar words in a context together; and finally, Question for clarification, require students to use the thinking skills that they are trying to develop.

However, the knowledge and application of metacognitive strategies by English teachers is of vital importance as is pointed out by O'Malley, Chamot, Stewner-Mazanares, Russo and Kupper (1985) emphasizing that "students without metacognitive approaches are essentially apprentices without direction or opportunity to review their progress, achievements and future directions" (p.561).

The metacognitive strategies are described briefly as well: Advanced organizer is used to introduce the lesson topic and illustrate the relationship between what the students are about to learn and the information they have already learned.

Delayed production, a process of combining various material inputs and immaterialinputs (plans, know-how) to make something for consumption (the output). Direct attention, planning their instruction around the student's prior knowledge, students gained a deeper understanding of the subject and developed fewer false beliefs about newly presented concepts. Selective attention, the process of focusing on a particular object in the environment for a certain period, so selective attention allows to tune out unimportant details and focus on what really matters.

Self-management, a form of organizational management based on self-directed work processes. Self- monitoring, an ability to regulate behavior to accommodate learning situations. Self-evaluation, a useful process that is rigorous and enables to be critically reflective about yourself. Finally, Selfreinforcement, a process whereby individuals control their own behavior by rewarding themselves when a certain standard of performance has been attained or surpassed.

Coady (1997) also highlights that knowledge and vocabulary management is of vital importance, as it was shown to be the best predictor of reading comprehension of $\mathrm{L} 1$ and L2. Therefore, the teaching-learning of vocabulary is an essential piece in the development of knowledge in another language.

Many investigations have been carried out on the strategies for learning vocabulary in English, most of them have focused only on cognitive strategies leaving aside metacognitive strategies 
and their direct relationship with vocabulary acquisition, which is why the following research question was proposed.

In this sense, what are the metacognitive strategies used by teachers at UCACUE Language Center to teach English vocabulary to students?

Taking into consideration that Chamot and O’Malley (1992) Coady (1997), and Oxford (1990) suggest that the knowledge of the metacognitive strategies from the teacher could help the students to get to know much better what metacognitive strategies work in each case, creating independence in the student.

Since vocabulary and metacognitive strategies are closely related, this research project attempts to bridge the gap between teachers' instructional practice and theories to enhance vocabulary learning. It is known that vocabulary plays a key role in the individuals' proficiency.

The research will be applied to the teachers of the Language Center in order to identify the metacognitive strategies most used by them to achieve vocabulary development. This research will also make reference to which are the metacognitive strategies used in the acquisition of vocabulary in English at the Language Center of the Catholic University of Cuenca.

The main objective of this research is to identify, the metacognitive strategies that teachers use during their classes for vocabulary development, the purpose of this research is to make teachers aware of their responsibility to promote vocabulary learning strategies for the English language.

\section{METHOD}

Exploratory research was conducted at the Language Center of the Catholic University of Cuenca, which provides English courses to the entire university educational community at different levels and schedules. The Language Center of the Catholic University of Cuenca has fourteen (14) professors in total of which eight (8) professors have a master's degree, and only three of them are related to the teaching of the English language who participated in the research voluntarily and keeping the respective confidentiality.

To collect the information, a questionnaire was constructed, previously validated by experts, classified in open questions related to the strategies used by the teachers to teach English vocabulary and they were consulted based on their experiences about the strategies they considered most effective for teaching English vocabulary, as a technique the survey was applied.

The information was collected face-to-face so that teachers had the possibility to describe the strategies used by themselves. The analysis of the information was carried out in two stages: a) first, a description of the data was made to typify the different types of strategies and identify their effectiveness and b) analyze the results based on the theory presented.

Given the scarcity or absence of educational research in the area of English language in Ecuador, it was necessary to conduct an exploratory study to delineate the teaching experience in the application and knowledge of metacognitive strategies.

\section{RESULTS AND DISCUSSION}

As a result of the first research question, some strategies that are used by the teacher in the process of teaching vocabulary were revealed, which are described as follows: 1) images; 2) contextualization; 3) repetition of words; 4) realia; 5) games; 6) graphic organizers, mind map; and 7) tests, word grouping, graded language, mime, songs, labeling and Word wizards.izzes, grouping words, graded language, mime, songs, labeling and Word wizards.

The Graph 1 shows the results where it is possible to see that the first strategy to teach vocabulary is Imagery followed by Contextualization. In addition, the repetition of words, resourcing and games as more outstanding strategies. 


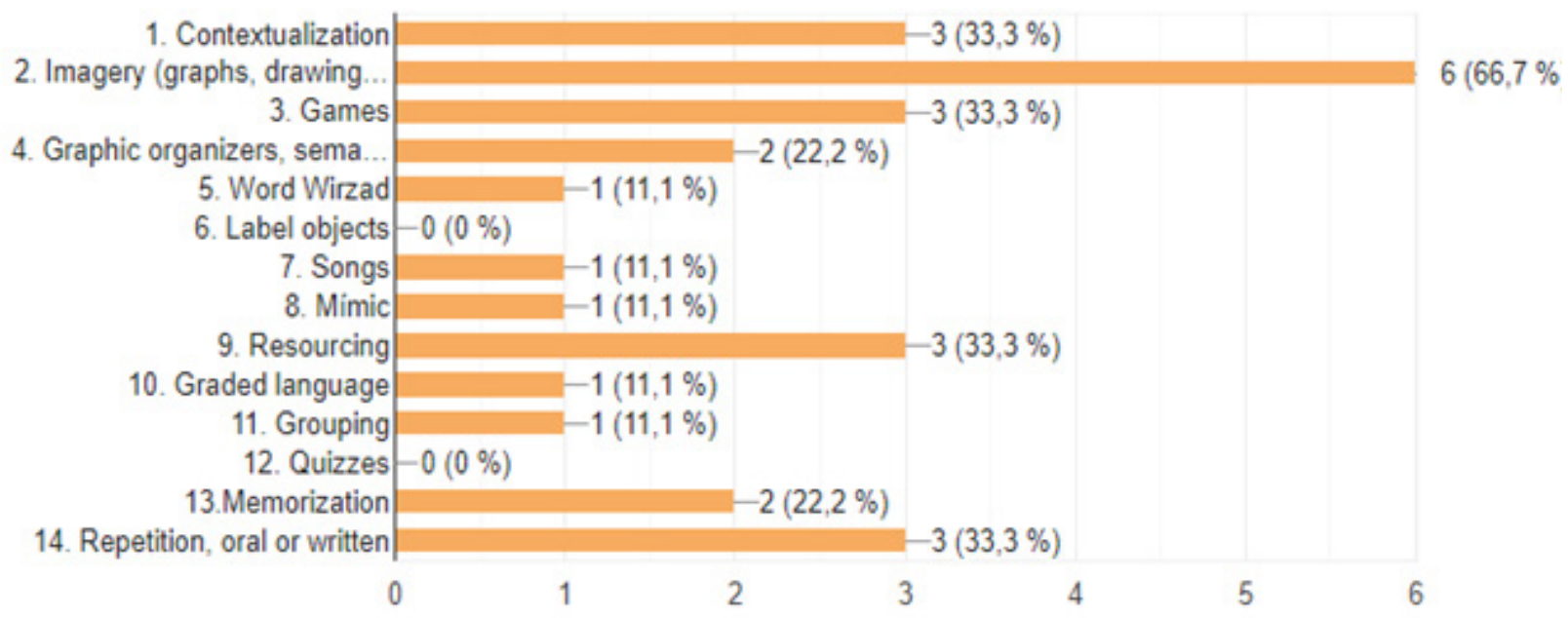

Graph 1. What strategies do you use to teach vocabulary in English?

As it can be seen, the strategies used by teachers are:

\section{1) Imagery}

According to the interview, the majority of the teachers agreed that the best way the students were able to comprehend vocabulary was through pictograms which included pictures, flash cards, drawings among others. They considered that when students were exposed to a visual aid, normally they learned easily the new words. Besides, they pointed out that the books, which are full color, contributed to achieve the goal of learning vocabulary.

\section{2) Contextualization}

Teachers considered that teaching vocabulary through context helped the students to comprehend much better new vocabulary without looking up a dictionary or translation. The readings were essential to achieve this goal and, in that sense, they mentioned that sometimes they started the class with readings depending on the content of the class.

\section{3) Repetition, oral or written}

Some teachers manifested that use the oral and written repetition strategies of the new words and in turn used them in sentences provided to the students the ability to acquire new vocabulary easily. Moreover, a teacher mentioned that through mechanization exercises, repetition, the use of new words in different contexts, and the use of drawings to know the meaning of the word helped to memorize vocabulary.

\section{4) Resourcing}

Teachers considered that to learn vocabulary a good strategy was the real contact with the object so that the student got a meaningful learning of the word.

\section{5) Games}

Teachers stated that the use of games promoted the learning of Vocabulary in class due to the fun atmosphere that a game creates, was the ideal to acquire new words.

\section{6) Graphic organizers, semantic mind maps, memorization}

Some teachers declared that the use of graphic organizers and semantic mind maps as well as memorization as a strategy to teach vocabulary, according to them the use of this tools improved considerably the usage of vocabulary in long term. Moreover, memorization. 
7) Quizzes, grouping words, graded language, mime, songs, labeling and word wizard

Some teachers mentioned at least one of the strategies above as part of their classes when they needed to be focused on vocabulary. Every one considered these strategies as part to combine strategies according to the topic the students are learning. Some teachers claimed that songs were good resource for Fridays, because the students were tired and no focused in classes.
Regarding the second question about the most effective strategy for teaching vocabulary in English the representation in the following graph it is appreciated that contextualization is the best strategy followed by the games and combination of several strategies. (Graphic 2).

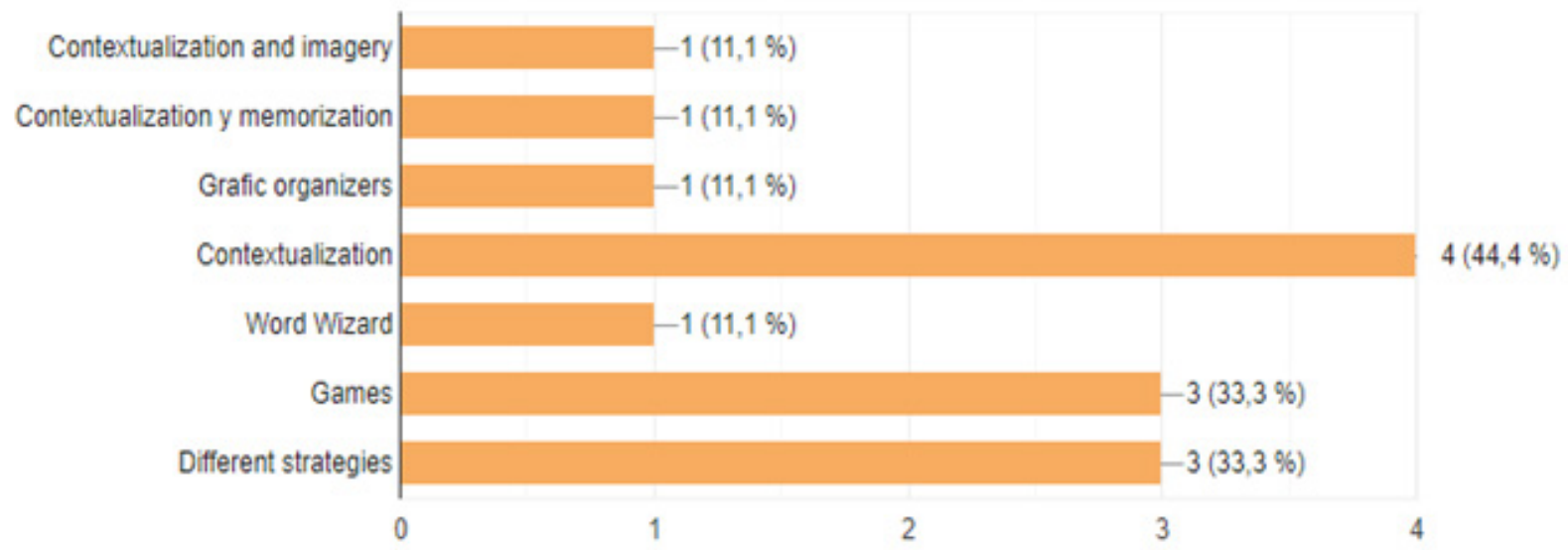

Graph 2. Which do you consider is the most effective strategy for teaching vocabulary in English?

\section{1) Contextualization}

The teachers described as the best strategy for students to learn vocabulary, they emphasised in the use of readings and sentences to have the appropriate context to discover the new words.

\section{2) Games}

Gamification as well, was considered as a very important strategy to teach vocabulary due to create a good atmosphere between peers and teachers for learning new vocabulary.

\section{3) Different strategies}

Most of the teachers agreed in a combination of different strategies provided a better result as to improving vocabulary. They highlighted contextualization and imagery and contextualization and memorization.

\section{4) Graphic organizers and word wizard}

Just few teachers highlighted the benefits of these strategies to improve vocabulary learning.

The questions were focused on answering the research question what are the metacognitive strategies used by teachers at UCACUE Language Center to teach English vocabulary to students?

In the following Table 1 it has been grouped 9 strategies within the three large groups defined by Larsen-Freeman: Cognitive, Metacognitive and Socio Affective. Additionally, the best strategy used to teach vocabulary in English at the Language Center. 
Table 1. Strategies considered the best according to the teachers interviewed.

\begin{tabular}{|c|c|c|c|c|}
\hline Profesor & Cognitiva & Metacognitiva & $\begin{array}{c}\text { Socio } \\
\text { afectiva }\end{array}$ & Mejor estrategia considerada por el docente \\
\hline 1 & $\mathrm{X}$ & & & Diferentes estrategias (Contextualization and imagery) \\
\hline 2 & $\mathrm{X}$ & & & Diferentes estrategias (Contextualization and imagery) \\
\hline 3 & $\mathrm{X}$ & & $\mathrm{X}$ & Games (Social affective) \\
\hline 4 & $\mathrm{X}$ & & $\mathrm{X}$ & Games (Social affective) \\
\hline 5 & $\mathrm{X}$ & $\mathrm{X}$ & $\mathrm{X}$ & Word Wizard (Metacognitivo) como trabajo cooperativo (Social affective) \\
\hline 6 & $\mathrm{X}$ & & & Contextualización (Cognitivo) \\
\hline 7 & & & & Graphic organizers (Metacognitivo) \\
\hline 8 & $\mathrm{X}$ & & & Contextualización and memorization (Cognitivo) \\
\hline 9 & $\mathrm{X}$ & & & Contextualización and Pictogramas (Cognitvo) \\
\hline
\end{tabular}

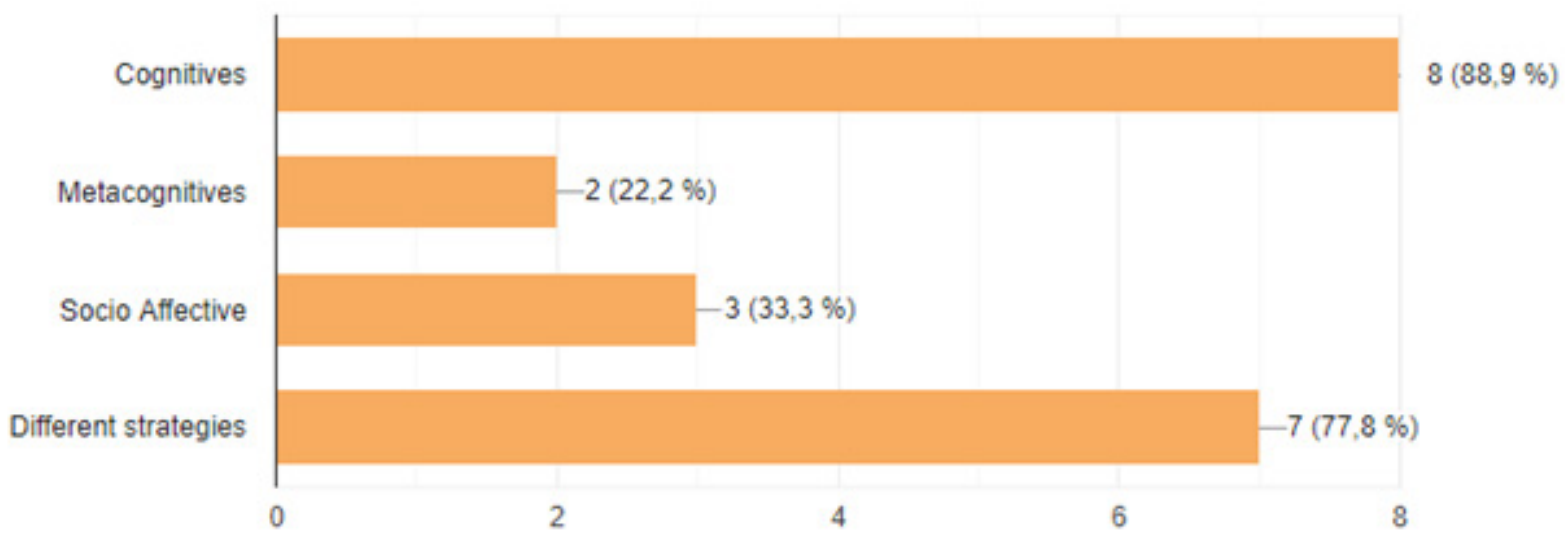

Graph 3. Strategies most commonly used by Language Center teachers for teaching English vocabulary.

As is shown in the Graph 3 that the most used strategies by the teachers of the Language Center for teaching vocabulary in English are Cognitive and the least used are Metacognitive. Indeed, the metacognitive strategies employed by the participants were Word Wizard and Graphic Organizers, which corresponded to $22.2 \%$ of all the strategies employed by the teaching group.

On the other hand, the most effective strategy according to the teaching criteria was Contextualization and Different strategies where the cognitive ones were mentioned mostly. In this same sense, within the metacognitive strategies mentioned by the teachers, the ones that were perceived as the most effective were Word Wizard and Graphic Organizer, strategies considered as a part of meaningful learning, this finding indicated that it cannot be evidenced that teachers applied the design of metacognitive tools that would allow to know the organization of the cognitive structure of the learner. 


\section{Discussion}

Regarding the general objective of this research, we have discovered that the most used strategies by the teachers of the Language Center for teaching vocabulary in English are Cognitive and the least used are Metacognitive. Since, the strategies of teaching vocabulary in another language is considered as an essential piece for learning of the target language, therefore the knowledge of the teachers about the strategies and how to use them is of vital importance.

It is evident that the participating teachers used metacognitive strategies to strengthen knowledge of English vocabulary to a minimum degree, a fact that may have an impact on learning outcomes. On this, He (2010) highlights the importance of the application of metacognitive strategies in vocabulary learning in his studio, the same as was carried out with two groups A and B, two instruments were used to collect the information, a questionnaire and an interview, the study was focused in seven strategies for learning vocabulary. The students in group a received instruction and guidance how to use the strategies, meanwhile the group B didn't received it. The results demonstrated that group a could manage the vocabulary strategies in a way that they improved their knowledge, on the contrary, group B found the strategies useless due to the lack of knowledge how to use them. As a result of this investigation, teachers teach vocabulary to the students guided by the cognitive strategies to acquire the knowledge but not guided by metacognitive, Jamaris (2016) therefore emphasizes in its research the importance of metacognitive strategies when mentioning that "students without metacognitive focuses are essentially learners without direction or opportunity to review their progress, achievements and future directions."

Another result of this investigation is that most teachers use strategies framed within the group of cognitive and socio affective. A minority group of teachers use only a group of strategies, whether they are only cognitive or metacognitive. According to the theoretical framework of this research, investigators agree that there is no single strategy that works for all groups equally, on the contrary it is considered that teachers must use different strategies considering the classification groups. In this line, the teachers are using either just one group of strategies or a combination of maximum two. Some studies have confirmed that a combination of strategies provide better results as is mentioned in the study carried out by Siatoba Navarrete, Forero Torres y García Forero, (2014), where it is showed how the implementation of strategies such as imagery and sentences in context, gave positive results due to it was possible to evidence the vocabulary improvement in the students, even though the students did not reach the hundred per cent of knowledge, confirming what Oxford stated about the storage and recuperation of new information is due to the necessity to link the previous knowledge with the new one. Therefore, it cannot be shown in this research that the teachers apply the design of metacognitive tools that allow knowing the organization of the cognitive structure of the learner, which would allow a better orientation of the educational work.

The learners have a series of experiences and knowledge that affect their learning and can be used for their benefit. On the other hand, teachers consider that the best strategy to teach vocabulary is the cognitive strategy of Contextualization firstly, secondly the socio-affective strategy of Games and a combination of other strategies. However, in the results obtained in the strategies of teachings the first place is occupied by Imagery, followed by Contextualization. However, the second most used strategy by teachers is not mentioned as one of the best in learning outcomes. The causes of this observation could be speculated as: lack of knowledge related to the alternatives or their way 
of use, moreover, it is appreciated that only three teachers use socio-affective strategies for teaching vocabulary the most prominent being the games.

For teaching vocabulary in the English language the metacognitive strategies are considered essential to guide the processes of significant learning to the students. Therefore, this parameter is fulfilled only partially in this research, since many factors could be interfering in this purpose, one of them could be the level of relevance of Language Center Teachers. Indeed, when reviewing the teacher profiles, it was observed that only three have a master's degree related to the English area.

Another related factor could be the lack of training for the use of metacognitive strategies with your students.

These results are consistent with what Miranda (2015) observed in a study that aimed to apply metacognitive learning strategies in the reading comprehension of English texts to obtain a high degree of interest in the topics set out and active participation of students. A qualitative research was carried out with a survey and questionnaire for teachers and students and the results obtained were a lack of knowledge of the metacognitive processes involved in learning and how to teach them, in addition to the fact that there are no supervision and regulation procedures that students implement on cognitive activity when performing a task, and finally that it is known the fact that in the process of teaching-learning the English language students are not warned of the importance of reflecting on their own knowledge and the way in which they are produced, not only knowledge, but also learning.

The support that metacognitive strategies would provide for the teaching, not only of the English language, but of many other areas, has been experimentally proven, as demonstrated in their study Zohreh y Reza (2003), who conducted experimental design research with pretest and postest, the subjects were assigned in two groups that were randomly assigned, the homogenity of the group on vocabulary knowledge was reviewed through the Nelson English Proficiency Test. Both groups received training based on learning strategies, but the experimental group received specific instruction of metacognitive strategies at the beginning of the second day of the course. The results obtained at the end of the course when applying the post-test were significant since the experimental group surpassed the control group in terms of vocabulary knowledge.

The Language Center of the Catholic University of Cuenca used mostly Cognitive strategies for teaching English Vocabulary, some of them have mentioned games as the single one connected to socio affective strategies and word wizard and graphic organizers as metacognitive. Furthermore, a minor group use only one strategy to teach vocabulary in English meanwhile the rest use different strategies. Contextualization seems to be the best strategy for teaching English Vocabulary in this Language Center.

\section{CONCLUSIONES}

Regarding the general objective of this research, it has been found that the strategies most used by the teachers of the Language Center for the teaching of vocabulary in English are of the Cognitive type, while the Metacognitive ones are less used.

Regarding the identification of metacognitive strategies, it was recognized, graphic organizer and word wizard. However, the most important ones are not mentioned, giving as a possibility the lack of knowledge of the real use of metacognitive strategies as part of the process not only for learning but also for teaching.

The teachers consider that the best strategy to teach vocabulary is the cognitive strategy of contextualization in the first place, in second place the socio-affective strategy of games. However, only three of the nine teachers use socio-affective 
strategies and do not mention the most prominent in terms of use, which is imagery.

Most teachers use strategies framed within the cognitive and metacognitive group. A minority group of teachers uses only one group of strategies, whether they are only cognitive or metacognitive.

Only one teacher applies strategies framed in the three groups: cognitive, metacognitive and socio-affective.

For the teaching of vocabulary in the English language, metacognitive strategies are considered fundamental to guide meaningfullearning processes to students, so this value is only partially fulfilled.

Therefore, it cannot be evidenced that teachers apply the design of metacognitive tools that allow to know the organization of the cognitive structure of the learner, which would allow a better orientation of the educational work, learners have a series of experiences and knowledge that affect their learning and can be used for their benefit.

As a recommendation, it is suggested to carry out an in-depth analysis of the use of the strategies to the groups that lead the teachers surveyed to know the significant learning processes applied.

\section{REFERENCIAS}

Cervantes. (1997). Centro Virtual Cervantes. Diccionario de términos on line. https://cvc. cervantes.es/ensenanza/biblioteca_ele/diccio_ ele/diccionario/estratcog.htm

Chamot, A. U., and O'Malley, J. M. (1992). The cognitive academic language learning approach: A bridge to the mainstream. In P. A. RichardAmato \& M. A. Snow (Eds.), The multicultural classroom: Readings for content-area teachers. White Plains: Longman. Retrieved from https://onlinelibrary.wiley.com/doi/ abs/10.2307/3586733

Essays, UK. (2018). The ImportanceOfTeaching And Learning Vocabulary English Language Essay. Retrieved from https://www.ukessays.com/ essays/english-language/the-importanceof- teaching-and-learning-vocabulary-englishlanguage-essay.php?vref=

García-López, M. (2000). Estrategias de aprendizaje de vocabulario de inglés utilizadas por los estudiantes de Secundaria. In G. L. Miguel., Estrategias de aprendizaje de vocabulario de inglés utilizadas por los estudiantes de Secundaria. (p. 61). Retrieved from https://ruc. udc.es/dspace/bitstream/handle/2183/8115/ LYT_15_2000_art_6.pdf

He, Y. (2010). A Study of L2 Vocabulary Learning Strategies. Kristianstad University The School of Teacher Education. China. Retrieved from https://www.diva-portal.org/smash/get/ diva2:326994/fulltext01.pdf

Jamaris, J. (2016). Metacognitive strategy for vocabulary learning. Ta’dib, 16(2) 187-191. Retrieved from https://ojs.iainbatusangkar. ac.id/ojs/index.php/takdib/article/view/251

Larsen-Freeman, D. L. (1991). Second language acquisition research: Staking out the territory. TESOL quarterly, 201-203. Retrieved from https://onlinelibrary.wiley.com/doi/ abs/10.2307/3587466

Miranda, G. (2015). Aplicación de un programa de estrategias metacognitivas para la comprensión lectora del idioma inglés en los estudiantes de tercer año de bachillerato de la unidad educativa fiscomisional Tirso de Molina" de la ciudad de Ambato, parroquia Izamba, provincia de Tungurahua en el año lectivo 2014 - 2015. Tesis de maestría. Ambato: Pontificia Universidad Católica de Ambato. Retrieved from https://repositorio.pucesa.edu.ec/ bitstream/123456789/1383/1/75772.pdf

O’Malley, J. M., Chamot, A. U., Stewner-Mazanares, G., Russo, R., \& Kupper, L. (1985). Learning strategies applications with students of English as a second language.TESOL Quarterly, 19, 28596. Retrieved from https://onlinelibrary.wiley. com/doi/abs/10.2307/3586278

O'Malley, J. M. (1990). Learning strategies in second language acquisition. New York: Cambridge University Press. 
Oxford, R. (1990). Language learning strategies. What every teacher should know. Heinle \& heinle Publishers, 166- 172. Retrieved from https://www.cnki.com.cn/Article/CJFDTotalJYWY200510011.htm

Siatoba Navarrete, A., Forero Torres, J. M., \& García Forero, J. M. (2014). Impacto de las estrategias de aprendizaje de vocabulario de inglés como lengua extranjera en la Fundación ASE. (Tesis pregrado). Universidad de la Salle. Bogotá. Retrieved from https:/ciencia.lasalle.edu.co/ lic_lenguas/479

Zohreh, R. y Reza, R. (2003). Metacognitive Strategy Training for Vocabulary Learning. The Electronic Journal for English as a Second Language [TESL-EJ], 7(2). Disponible en http:// www.tesl-ej.org/wordpress/issues/volume7/ ej26/ej26a5/?em_x=22 